\title{
PELATIHAN MANAJEMEN PENINGKATAN \\ PRODUKTIVITAS REMAJA DI MASA PANDEMI COVID 19 PADA PKBM INSAN SATYA GUNA (PKBM INTAN)
}

Putri Nilam Kencana, Iis Noviyanti, Baliyah Munadjat, Windy Gustia Wardani, Uswatun Chasanah

Dosen Ekonomi Fakultas Ekonomi Universitas Pamulang

Email dosen 01877@unpam.ac.id , dosen01107@unpam.ac.id, dosen02162@unpam.ac.id, dosen01579@unpam.ac.id, dosen02021@unpam.ac.id

\begin{abstract}
ABSTRAK
Pengabdian ini berjudul Pelatihan Manajemen Peningkatan Produktivitas Remaja di Masa Pandemi Covid 19 pada PKBM Insan Satya Guna (PKBM INTAN)"

Tujuan pengabdian ini adalah Memberikan pengarahan kepada warga belajar PKBM Insan Satya Guna agar dapat meningkatkan kemampuan dan produktivitasnya dalam berwirausaha terutama di masa pandemi Covid 19Agar warga belajar PKBM Insan Satya Guna dapat meningkatkan produktivitasnya di masa pandemi Covid 19 melalui penyuluhan yang di berikan oleh Dosen-dosen Universitas Pamulang.

Metode pelaksanaan pengabdian ini adalah memberikan penyuluhan serta diskusi dalam konteks memberikan pelatihan dan pengarahan kepada para remaja warga belajar PKBM Insan Satya Guna agar dapat meningkatkan produktivitasnya di masa pandemic Covid 19 saat ini melalui daring dengan aplikasi google meeting. Adapun tahapan YANG dilakukan adalah Tahapan Persiapan dan Pelatihan .

Kesimpulan dari pengabdian ini adalah Kegiatan Pengabdian Kepada Masyarakat (PKM) yang telah kami lakukan ini pada dasarnya adalah berkat kerjasama berbagai pihak terkait sehingga kegiatan dapat berjalan dengan baik dan terukur, serta materi yang kami sampaikan dapat warga belajar PKBM Insan Satya Guna. Dengan adanya kegiatan Pengabdian Kepada Masyarakat (PKM) ini, diharapkan peserta dapat mengaplikasikan ilmu yang telah mereka peroleh dalam kehidupan sehari-hari. Dan pada akhirnya, ilmu tersebut dapat dirasakan manfaatnya oleh peserta sendiri dan lingkungan di sekitarnya, khususnya lingkungan warga belajar PKBM Insan Satya Guna.
\end{abstract}

\section{Kata Kunci: Manajemen , Produktivitas , PKBM}

\section{ABSTRACT}

This service was entitled Management Training for Increasing Youth Productivity during the Covid 19 Pandemic at the Satya Guna PKBM (PKBM INTAN) "

The purpose of this service is to provide direction to the Satya Guna PKBM learning citizens so that they can increase their ability and productivity in entrepreneurship, especially during the Covid 19 pandemic. Pamulang University. 
The method of implementing this service is to provide counseling and discussion in the context of providing training and briefing to Satya Guna PKBM youth learning citizens so that they can increase their productivity during the current Covid 19 pandemic through online with the google meeting application. The stages that are carried out are the Preparation and Training Stages.

The conclusion of this service is that the Community Service Activities (PKM) that we have carried out are basically thanks to the cooperation of various related parties so that the activities can run well and measured, as well as the material we convey can residents learn PKBM Insan Satya Guna. With this Community Service (PKM) activity, it is hoped that participants can apply the knowledge they have gained in their daily lives. And in the end, the benefits of this knowledge can be felt by the participants themselves and the environment around them, especially the learning environment of the Insan Satya Guna PKBM learning community.

\section{Keywords: Management, Productivity, PKBM}

\section{PENDAHULUAN}

Kegiatan pengabdian masyarakat merupakan salah satu Tri Dharma Perguruan Tinggi Selain Pendidikan dan Penelitian, sesuai undang-Undang RI Nomor 20 Tahun 2003 tentang Sistem Pendidikan Nasional, pada Pasal 20 ayat 2 dinyatakan:

"Perguruan

Tinggiberkewajiban menyelenggarakan pendidikan, penelitian dan pengabdian masyarakat". Pada Pasal 24 ayat 2 disebutkan:"Perguruan tinggi memiliki otonomi untuk mengelola sendiri lembaganya sebagai pusat penyelenggaraan pendidikan tinggi, penelitian ilmiah, dan pengabdian masyarakat"

Tidak ada yang menyangkal bahwa pendidikan adalah hak dan kewajiban bagi setiap insan. Maka dengan itu tidak satupun orang diperkenan meninggalkan pendidikan, terlepas soal usia, keyakinan, ras, budaya, hak kepemilikan, dan juga stratanya. Dalam kontek Negara Indonesia, hal ini tercantum dalam UUD 1945 Pasal 31 Ayat 1-2 dan Pasal 28C. Walaupun demikian, di negara tercinta kita ini masih sangat banyak masyarakat yang tak mengenyam pendidikan, baik disebabkan oleh keterbatasan jangkauan kebijakan pemerintah maupun keenganan masyarakat itu sendiri untuk belajar atau bersekolah.
Tanggung jawab pembangunan pendidikan sebagaimana yang tertuang dalam Undang-Undang Nomor 20 tahun 2003 tidak saja menjadi tanggung jawab pemerintah namun juga menjadi tugas dan tanggung jawab bersama antara masyarakat dan pemerintah. Akselerasi tujuan pendidikan pada prinsipnya harus dilaksanakan oleh lembaga pendidikan formal, non formal dan informal yang menjadi bagian tak terpisahkan dalam mewujudkan tujuan pendidikan Nasional

Fakta di masyarakat menunjukkan bahwa keberhasilan pendidikan di sekolahan formal belum mampu menjangkau pemerataan pendidikan kepada masyarakat. Itulah sebabnya pendidikan non formal menjadi faktor yang penting guna tercapainya pemerataan pendidikan.

Diakui atau tidak saat ini jumlah siswa yang terancam putus sekolah terus meningkat, khususnya siswa pada jenjang pendidikan dasar Sembilan tahun. "Bank Dunia dalam laporannya mensinyalir bahwa dampak dari krisis ekonomi yang tidak kunjung usai, adalah anjloknya Angka Partisipasi Sekolah (APS), terutama anakanak yang berasal dari keluarga miskin. Serta merosotnya kualitas sekolah, yang sebenarnya sebelum ke tahap kritis, tapi sudah sangat mengkhawatirkan. 


\section{JURNAL ABDIMAS

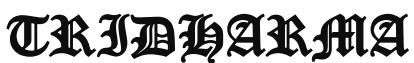

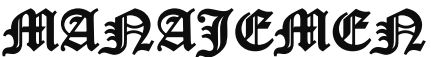

P-ISSN 2715-7105, E-ISSN 2716-070X

Jurnal ABDIMAS Vol. 2, No. 1,Januari 2021,Hal (112-119)

@Prodi Manajemen Fakultas Ekonomi Universitas Pamulang

Email: abdimasjurnal.unpam@ gmail.com Telp: (021) 741-2566
Padahal keterlibatan masyarakat sudah diamanatkan dalam Undang-undang 20 tahun 2003, tentang sistim pendidikan nasional yang menyatakan bahwa "Masyarakat berkewajiban memberikan dukungan su mberdaya dalam penyelenggaraan pendidikan". Sehingga tanggung jawab pembangunan pendidikan tidak saja menjadi tanggung jawab pemerintah namun juga menjadi tugas dan tanggung jawab bersama antara masyarakat dan pemerintah. Akselerasi tujuan pendidikan pada prinsipnya harus dilaksanakan oleh lembaga Pendidikan Formal, non formal dan informal yang menjadi bagian tak terpisahkan dalam mewujudkan tujuan pendidikan Nasional.

Menurut Hasibuan (2012:1) Manajemen yaitu: "Ilmu dan seni mengatur proses pemanfaatan sumber daya manusia dan sumber-sumber lainnya secara efektif dan efisien untuk mencapai suatu tujuan tertentu"

Sedangkan menurut Manullang dalam bukunya Dasar-dasar Manajemen (2011:5) Manajemen yaitu: "seni ilmu perencanaan, pengorganisasian, dalam pengabdian kali ini, dimaksudkan untuk penyusunan, pengarahan dan pengawasan untuk mencapai tujuan yang sudah ditetapkan".

Dalam pelaksanaannya, lembaga pendidikan non formal ini (termasuk PKBM Insan Karya) masih terseok-seok, karena masih ada kekurangan dari sanasininya, terutama yang berkaitan dengan SDM-nya maupun dengan alat-alat yang mendukung. Bantuan pemerintah yang ada selama ini belum mampu menjadikan lembaga pendidikan non formal tersebut mengalami perkembangan (dalam arti signifikan), apalagi mandiri. Oleh karena itu kami melakukan pengabdian kepada masyarakat yang bertema "Pelatihan Manajemen Peningkatan Produktivitas Remaja di Masa Pandemi Covid 19 pada PKBM Insan Satya Guna (PKBM INTAN)"

\section{RUMUSAN MASALAH}

Berdasarkan latar belakang masalah di atas, maka dapat dirumuskan permasalahannya sebagai berikut:

1.Mengapa diperlukan pelatihan manajemen peningkatan prpoduktivitas remaja di masa Pandemi Covid 19 pada PKBM Insan Insan Satya Guna?

2.Bagaimana warga belajar PKBM Insan Satya Guna dapat meningkatkan produktivitas di masa pandemic Covid 19 ?

\section{TUJUAN PELAKSANAAN}

Tujuan yang ingin dicapai dalam kegiatan pengabdian kepada masyarakat ini adalah sebagai berikut:

1. Memberikan pengarahan kepada warga belajar PKBM Insan Satya Guna agar dapat meningkatkan kemampuan dan produktivitasnya dalam berwirausaha terutama di masa pandemi Covid 19

2. Agar warga belajar PKBM Insan Satya Guna dapat meningkatkan produktivitasnya di masa pandemi Covid 19 melalui penyuluhan yang di berikan oleh Dosen-dosen Universitas Pamulang.

\section{TINJAUAN PUSTAKA}

\section{MANAJAMEN}

Manajemen hanya merupakan alat untuk mencapai tujuan yang diinginkan. Manajemen yang baik akan memudahkan terwujudnya tujuan perusahaan/organisasi. Unsur-unsur manajemen terdiri dari : man, money, method, machines, materials, dan market, disingkat $6 \mathrm{M}$. Manajemen berasal dari kata : "to manage" yang artinya mengatur. Apa yang diatur, apa yang diatur,mengapa harus diatur, siapa yang mengatur dan bagaimana mengaturnya. 
Menurut Hasibuan (2016:1) bahwa manajemen adalah ilmu dan seni mengatur proses pemanfaat proses pemanfaatan sumber daya manusia dan sumber-sumber lainnya secara efektif dan efisien untuk mencapai suatu tujuan tertentungan dan peranan tenaga kerja agar efektif dan efisien membantu terwujudnya tujuan perusahaan, karyawan dan masyarakat".

\section{PRODUKTIVITAS}

Edy Sutrisno (2015:101) mengemukakan produktivitas adalah perbandingan antara output (hasil) dengan input (masukan). Jika produktivitas naik ini hanya dimungkinkan oleh adanya peningkatan efisiensi (waktu-bahan-tenaga) dan sistem kerja, teknik produksi dan adanya peningkatan keterampilan dari tenaga kerjanya. Dari berbagai pengertian premi asuransi menurut para ahli di atas, dapat disimpulkan bahwa pengertian produktivitas adalah perbandingan antara keluaran (output) dengan masukan (input).PKBM

PKBM Insan Satya Guna melibatkan banyak komponen masyarakat untuk menjadi penguat organisasi, sebagai pengajar dan juga sukarelawan. Mayoritas warga belajar PKBM Insan Satya Guna adalah anggota masyarakat yang sebagian besar remaja yang putus sekolah. Sebagian dari mereka sudah ada yang bekerja atau memiliki usaha. Tetapi ada juga yang masih melakukan kegiatan-kegiatan serabutan untuk memenuhi kebutuhan hidupnya, misalnya dengan menjadi pengemudi online, membantu usaha-usaha rumahan dan lain-lain. Bagi mereka yang sudah memilki usaha di beri pelatihan dan pengarahan agar usaha nya dapat berjalan dengan baik salah satau nya adalah dengan pengarahan berkaitan dengan komunikasi dan teknik atau strategi pemasaranya. Sedangkan bagi warga belajar PKMB Insan Satya Guna yang masih belum bekerja atau masih bekerja serabutan di motivasi untuk membuka usaha dengan diberikan pelatihan tentang mencari ide usaha dan menangkap peluang di masa pandemic Covid 19 saat ini.

Kepada warga belajar diberrikan motivasi agar dapat mengidentivikasi kemampuan/bakat yang ada di dalam dirinya untuk dapat dikaitkan dengan peluang-peluang yang ada di masa pandemic Covid 19 saat ini. Saat ini, Ketika Sebagian besar orang harus bekerja dari rumah dan selalu menerapkan protocol Kesehatan, maka banyak sekali kegiatan yang berubah yang secara otomatis merubah juga kebutuhan-kebutuhan mereka. Perubahan gaya hidup dan kebutuhan tersebut akan menjadi peluang baru bagi pelaku wirausahawan untuk memenuhi kebutuhan-kebutuhan tersebut. Oleh karena itu diperlukan stategi dalam meningkatkan kepekaan terhadap peluang kewirausahaan yang artinya menigkatkan produktivitas remaja (warga bekajar PKBM Insan Satya Guna). Hanya mereka yang peka terhadap peluanglah yang dapat produktif dan berdaya guna di masa pandemic covid 19 saat ini.

\section{METODE PELAKSANAAN}

Metode yang digunakan dalam kegiatan Pengabdian Kepada Masyarakat (PKM) ini adalah memberikan penyuluhan serta diskusi dalam konteks memberikan pelatihan dan pengarahan kepada para remaja warga belajar PKBM Insan Satya Guna agar dapat meningkatkan produktivitasnya di masa pandemic Covid 19 saat ini melalui daring dengan aplikasi google meeting. Adapun tahapan-tahapan yang dilakukan dalam kegiatan ini yaitu: 


\section{Tahapan Persiapan}

a. Mengirimkan proposal kegiatan Pengabdian Kepada Masyarakat (PKM) kepada Universitas Lampung.

b. konfirmasi kepada ketua PKBM Insan Satya Guna untuk pelaksanaan kegiatan pelatihan dan penyuluhan

c. Pembagian kerja (jobdesk) anggota kelompok PKM.

d. Penyusunan bahan/materi yang akan dibawakan saat kegiatan PKM berlangsung.

\section{Tahapan Pelatihan}

a. Melakukan pemetaan terhadap kegiatan warga belajar PKBM Insan Satya Guna mengenai apa saja yang telah dilakukan warga belajar PKBM Insan Satya Guna

b. Memberikan materi mengenai pentingnya peningkatan produktivitas di masa pandemic Covid 19 ini kepada remaja warga belajar PKBM Insan Satya Guna.

c. Memberikan materi peningkatan kemampuan untuk menemukan ide usaha di masa pandemic Covid 19 pada warga belajar PKBM Insan Satya Guna (Webinar 1)

d. Memberikan materi peningkatan kemampuan untuk menangkap peluang usaha di masa pandemic Covid 19 pada warga belajar PKBM Insan Satya Guna

e. Memberikan materi menyusun rencana bisnis sederhana untuk mewujutkan ide usaha menjadi kegiatan produktif yang dapat menjadi tambahan atau alternatif sumber penghasilan bagi remaja warga belajar PKBM Insan Satya Guna

e. Mengadakan sesi diskusi untuk saling memberikan informasi mengenai kesulitan dan hambatan dalam menemukan ide, menangkap peluang dan merencanakan kegiatan usaha di masa pandemic Covid 19 untuk remaja warga belajar PKBM Insan Satya Guna.

\section{HASIL DAN PEMBAHASAN}

Kegiatan Pengabdian pada masyarakat (PKM) ini digagas oleh Dosen Universitas Pamulang bersama dengan Pengelola PKBM Insan Satya Guna.
Kegiatan PKM dimulai dengan mengunjungi PKBM Insan Satya Guna yang berlokasi di Muncul, Tangerang Selatan. Kegiatan PKM ini dilaksanakan setelah mengusulkan proposal yang telah kami buat agar kegiatan PKM agar dapat direalisasikan bersama.

Adapun judul kegiatan PKM ini adalah "Pelatihan Manajemen Peningkatan Produktivitas Remaja pada PKBM Insan Satya Guna". Judul ini kami anggap penting karena warga belajar PKBM yang sebagian besar adalah remaja putus sekolah. Sebagian dari mereka sudah ada yang bekerja atau memiliki usaha sendiri. Sebagian juga ada yang melakukan bekerja serabutan dengan membantu kegiatan usaha nonformal atau menjadi reseller dari sebuah produk. Tetapi di masa pandemic Covid 19 ini,sebagian warga belajar, ada yang terkena PHK, dan Sebagian besar usaha yang mereka jalankan terdampak pandemi. Oleh karena itu sangat dibutuhkan ketrampilan untuk meningkatkan produktivitas warga belajar dengan menemukan ide usaha baru yang sesuai dengan bakar/potensi pribadi dan sesuai juga dengan kebutuhan masyarakat/peluang yang ada.

Pada masa pandemic Covid 19 ini, masyarakat dihadapkan pada norma, budaya dan kebutuhan yang berubah (new normal). Hal tersebut secara otomatis membuka peluang usaha baru yang dapat dikembangkan menjadi bisnis/usaha. Dengan adanya penyuluhan ini diharapkan warga belajar PKBM Insan Satya Guna dapat meningkatkan produktivitasnya dengan meningkatkan kemampuan untuk menggali ide dan menemukan peluang usaha baru di tengah pandemic Covid 19 . Melalui pelatihan ini warga belajar PKBM Insan Satya Guna diharapkan belajar lebih banyak mengenai manajemen peningkatan produktivitas dengan menggali ide usaha dari dalam diri sendiri ataupun dari peluang yang ada serta mampu membuat rencana bisnis di tengah pandemic Covid 19. Membangun ide bisnis di masa pandemic Covid 19 ini merupakan tantangan yang 
berbeda, oleh karena itu dibutuhkan peningkatan produktivitas melalui peningkatan kemampuan membangun usaha baru yang sesuai dengan kebutuhan masayarakat di masa pandemic Covid 19. Di masa pandemic Covid 19 ini banyak sekali kebutuhan masyarakat yang berubah, yang artinya membuka peluang usaha baru. Untuk itu diperlukan peningkatan kemampuan dari warga belajar PKBM Insan Satya Guna dalam menggali ide dan menemukan peluang di tengah pandemic Covid 19 saat ini. Dengan kemampuan itu maka diharapkan warga belajar PKBM Insan Satya Guna dapat meningkatkan produktivitasnya yang secara otomatis dapat meningkatkan pendapatan/ perekonomiannya.

Dalam webinar hari pertama, diisi oleh materi pertama oleh Uswatun Chasanah, S.P.,M.M dengan judul materi Menemukan Ide dan Peluang Usaha di masa Pandemi Covid 19. Pada materi tersebut dikemukanan bahwa ide usaha dapat berasal dari potensi yang ada dalam diri sendiri baru dikaitkan dengan peliuang yang ada di masyarakat atau sebaliknya dari penemuan peluang yang ada di masyarakat baru dikaitkan dengan potensi yang ada dalam diri sendiri. Dalam istilah manajemen dikenal sebagai inside-out dan outside-in. Semakin kita banyak peduli dan mampu memahami kebutuhan orang lain, maka kita akan banyak menemukan peluang-peluang yang dapat dijadikan ide usaha. Jadi sebenarnya bisnis atau usaha adalah sesuatu yang kita lakukan untuk dapat menjadi solusi bagi permasalahan orang lain/masyarakat. Atau dengan kata lain bisnis dilakukan untuk dapat memenuhi kebutuhan masyarakat sesuai dengan segmentasi pasar yang dituju.

Pada Webinar hari kedua, materi disampaikan oleh Baliyah Munadjat, S.E,M.M., dengan judul Materi Meningkatkan efektifitas pemasaran melalui Segmentasi pasar. Dalam materinya Baliyah Munadjat, S.E,M.M. diterangkan bahwa untuk dapat melakukan pemasaran yang lebih efektif maka pelaku usaha harus menentukan segmentasi pasar dari produk yang dibuat. Segmentasi pasar yang dimaksud meliputi segmentasi perilaku, segmentasi psychographis, segmentasi demografis, dan segmentasi geografis. Dengan penentuan segmentasi pasar yang jelas dan akurat maka pelaku bisnis dapat menentukan cara dan konten pemasaran yang disesuaikan dengan segmen pasar yang dituju.

Pada Webinar hari ketiga, materi disampaikan oleh Iis Noviyanti,S.P., M.M, dengan judul Materi Meningkatkan produktivitas remaja melalui kemampuan perencanaan bisnis di masa pandemi Covid 19. Dalam materinya Lia Asmalah, S.Pd., M.M., menerangkan bahwa dalam masa pandemi ini untuk membangun usaha tidak hanya diperlukan ide usaha yang brilian tetapi juga diperlukan perencaaan yang matang dari pengembangan ide tersebut. Perencaan usaha meliputi perencanaan manajemen, perencanaan produksi, perencanaan pemasaran dan perencanaan keuangan. Perencanaan manajemen meliputi perencanaan organisasi, pengelolaan karyawan, lingkungan kerja, motivasi, pelatihan dan pemberian kompensasi terhadap karyawan. Perencaan Produksi meliputi, proses produksi, lokasi, design, tata letak, rancangan produk dan juga jumlah produksi. Sedangkan untuk perencanaan pemasaran perlu identifikasi dalam hal, segmentasi target pasar, karakteristik produk, penentuan harga, distribusi dan promosi. Untuk perencanaan keuangan diperlukan perkiraan penghasilan, pengeluaran dan keuntungan dari bisnis yang direncanakan, modal yang diperlukan.

Pelatihan ini diberikan kepada warga belajar PKBM Insan Satya Guna yang notabenenya adalah remaja putus sekolah yang sebagian besar terdampak oleh pandemi Covid 19. Sebagian warga belajar ada yang sudah bekerja atau memiliki usaha informal. Karena dampak pandemi covid 19, Sebagian warga belajar yang bekerja terkena pemutusan hubungan kerja (PHK) dan warga belajar yang 
memiliki usaha, mendapatkan penghasilan yang semakin tidak menentu karena omzet menurun dan menurunnya daya beli masyarakat. Dengan adanya dampak pandemic Covid 19 yang meluas dan tidak dapat dihindari maka perlu adanya peningkatan kemampuan pada warga belajar PKBM Insan Satya Guna untuk dapat meningkatkan produktivitasnya dengan mengembangkan ide dan menangkap peluang-peluang usaha di tengah masyarakat yang disesuaikan dengan potensi pribadinya. Dengan peatihan ini diharapkan wara belajar PKBM Insan Satya Guna memiliki kemampuan untuk dapat mengembangkan ide dan menangkap peluang usaha di tengah pandemi Covid 19. Dalam peningkatan produktivitas warga belajar PKBM Insan Satya Guna tersebut tidak hanya dibutuhkan ide yang brilian dan peluang yang terbuka lebar tetapi juga diperlukan perencanaan usaha yang terstruktur dengan baik.

Pembekalan materi melalui kegiatan PKM dosen Umuversitas Pamulang ini diharapkan dapat membuka wawadan dan juga meningkatkan ketrampilan warga belajar untuk menjadi lebih produktif di masa pandemic Covid 19 saat ini. Dengan tambahan pembekalan perencanaan usaha maka usaha yang dirancang oleh warga belajar PKBM Insan Satya Guna diharapkan dapat bersaing dan berkembang dengan baik

\section{KESIMPULAN DAN SARAN}

\section{Kesimpulan}

Kegiatan Pengabdian Kepada Masyarakat (PKM) yang telah kami lakukan ini pada dasarnya adalah berkat kerjasama berbagai pihak terkait sehingga kegiatan dapat berjalan dengan baik dan terukur, serta materi yang kami sampaikan dapat warga belajar PKBM Insan Satya Guna. Dengan adanya kegiatan Pengabdian Kepada Masyarakat (PKM) ini, diharapkan peserta dapat mengaplikasikan ilmu yang telah mereka peroleh dalam kehidupan sehari-hari. Dan pada akhirnya, ilmu tersebut dapat dirasakan manfaatnya oleh peserta sendiri dan lingkungan di sekitarnya, khususnya lingkungan warga belajar PKBM Insan Satya Guna.

Saran

Dari hasil pengabdian kepada masyarakat ini kami merekomendasikan kepada pemerintah dan dinas setempat agar

1. dengan adanya pelatihan ini kami melihat bahwa warga belajar sangat membutuhkan adanya pelatihan secara berkesinambungan yang tentang pengembangan usaha dan pemasaran melalui berbagai sarana aktivitas penunjang dalam masa pandemi.

2. PKBM sebagai tempat belajar diharapkan dapat memfasilitasi warga belajar untuk dapat memperoleh pelatihan pengembangan usaha dan pemasaran melalui aplikasi digital.

3. Pemerintah daerah diharapkan dapat membantu kegiatan pengembangan usaha kecil melalui kegiatan belajar di PKBM.

4. Institusi beserta akademisi diharapkan dapat berperan aktif untuk melakukan kegiatan pengabdian kepada masyarakat yang terkait dengan pengembangan usaha and pemasaran.

\section{DAFTAR PUSTAKA}

Edy, Sutrisno, (2016), Manajemen Sumber Daya Manusia, Kencana Prenada Media Group, Jakarta.

Hasibuan, Malayu. 2012. "Manajemen Sumber Daya manusia". Jakarta: PT BumiAksara.

M. Manulang, 2011, Manajemen Personalia , Jakarta: PT Aksara Baru.

Sinungan,Muchdarsyah.2014.Prod uktivitas Apa danBagaimana.cetakan ke9.Jakarta:Bumi Aksara

\section{DOKUMENTASI FOTO KEGIATAN}


JURNAL ABDIMAS

P-ISSN 2715-7105, E-ISSN 2716-070X

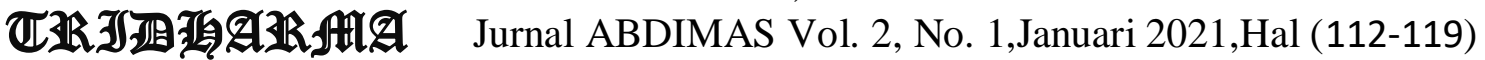

@Prodi Manajemen Fakultas Ekonomi Universitas Pamulang

Email: abdimasjurnal.unpam@ gmail.com Telp: (021) 741-2566
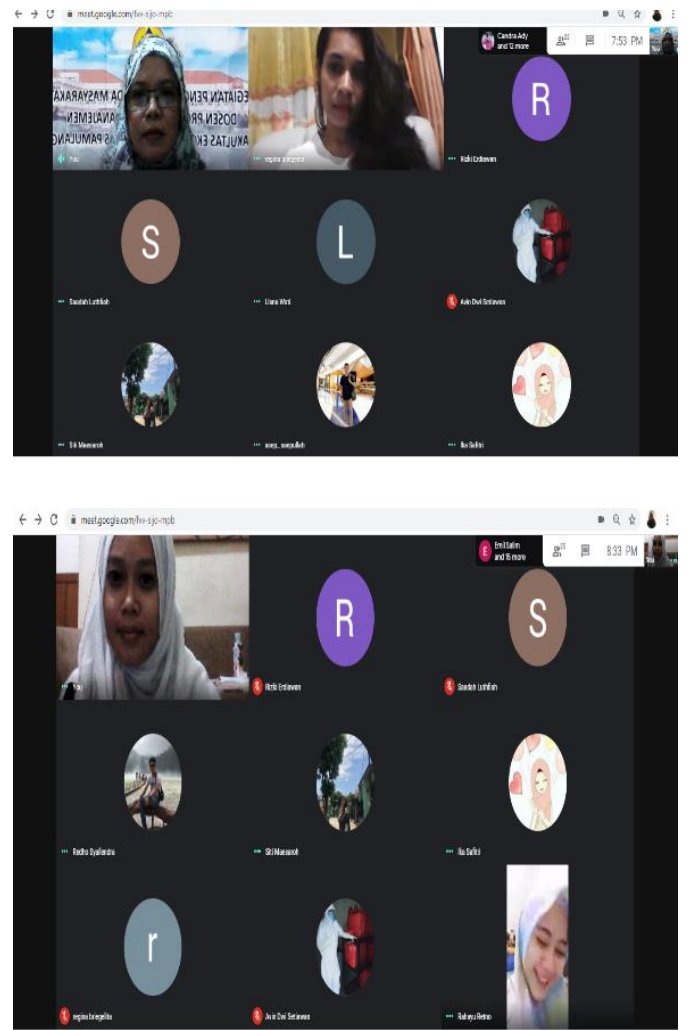